\title{
WHEN FACEBOOK IS THE INTERNET
}

\author{
A Halfie Anthropologist Grapples with Evolving Social \\ Media Connectivity
}

Rosa Cordillera A. Castillo

\begin{abstract}
My social media engagement with research interlocutors is shaped by my positionality as a 'halfie' anthropologist based abroad who conducts ethnographic research on violence and peacemaking in the Philippines and the diaspora. On the one hand, social media connectivity facilitates certain research processes, networking, activism, and solidarity building. Yet with social media's security issues and amid shifting political tides, such connectivity poses ethical and security risks, resulting in social media-specific ethical concerns. I demonstrate these points through an account of my engagement with Facebook, a ubiquitous platform for communicating among Filipinos. In the process, I reflect on some of the ways in which social media connectivity between researcher and interlocutors reconfigures the relationality, temporality, hierarchies, and affect of the ethnographic 'field'.
\end{abstract}

Keywords: co-presence, ethical issues, halfie anthropologist, Philippines, politics, positionality, security risks

In my country, the Philippines, Facebook is a primary platform for staying in touch; accessing, disseminating, and reacting to news and information; and mobilizing people for political and civic endeavors in the country and in the diaspora. A staggering 75 million Filipinos used Facebook in 2019, many of whom accessed it through their mobile phones, which render social media a constant presence in people's lives (Kemp 2019). Indeed, in the Philippines, "Facebook essentially is the Internet" (Ressa 2019). This context, and more generally the growth of social media, has profound implications for ethnographic fieldwork. 
Drawing on my experiences as a 'halfie' anthropologist based abroad who carries out ethnographic research on violence and peacemaking in the Philippines and the diaspora, I discuss how, on the one hand, being connected on social media with research interlocutors facilitates certain research processes, networking, activism, and solidarity building. Yet with Facebook's security issues and amid shifting political currents, such connectivity can pose risks to the anonymity and security of both researcher and her interlocutors. I demonstrate these points through an account of my evolving engagement with Facebook (FB). In the process, I reflect on some of the ways in which social media connectivity reconfigures the relationality, hierarchies, temporality, and affect of the ethnographic 'field'.

\section{Social Media Connectivity: Unsettling 'Home', 'Field', and Power}

The ethnographic 'field' is increasingly shaped by technology and the online sphere, in conjunction with practical, personal, professional, disciplinary, and geopolitical considerations (Gupta and Ferguson 1997). This is the case even if the researcher is not doing online ethnography as a primary method but is nevertheless connected to her interlocutors and research contexts through social media. This connectivity can produce a sense of 'co-presence' (Beaulieu 2010) that accrues from mediated social interaction instead of mere physical proximity. FB Messenger, for example, enables the researcher to constantly keep in touch with interlocutors in instantaneous and multi-sensorial ways through video, voice call, texts, emojis, and images. Furthermore, this platform enables a researcher to see facets of her interlocutors' lives, views, and feelings in ways that might be difficult otherwise. These are affective and sensorial interactions that point to how 'the field' as an "embodied relational process" (Spencer 2011: 73) is present in social media as well (Hine 2015: 51).

Meanwhile, whereas before it was mainly 'us' researchers who would inquire about the personal lives of our interlocutors, now interlocutors on social media can see, comment on, and inquire about our lives, especially if we post personal updates on social media. While this might feel uncomfortable (Hine 2015: 72), reciprocal social media use nevertheless gives our interlocutors the opportunity to challenge hierarchies and renegotiate the ethnographic gaze. Additionally, posting about our research on social media allows our interlocutors and the broader public to more easily access and engage with our work on their own terms. As such, our audiences have expanded and become empowered, raising questions not only about what we write but also about how and for whom we write. These dynamics suggest that social media connectivity may help unsettle the authoritative position of the academic as knowledge producer and put a spotlight on our multiple accountabilities. 
While constant connectivity, flow of information, embodiment, and copresence are valuable for our research and for forging closer bonds with certain interlocutors, it can also be overwhelming as the 'home' becomes increasingly enmeshed with 'the field'. The field's presence in our homes through regular social media connectivity can blur the temporal, mental, and affective divides between our personal and professional lives. In my experience, since most of the content on my FB News Feed is about the Philippines and thus almost always relevant to my research, personal, and political interests, I find it difficult to turn off my academic and political lens. For many hours every day, I am immersed in information and conversations. This immersive and overwhelming character of social media at times brings about the desire to withdraw or escape from it. And yet, I am pulled by it. It is compelling.

I suggest that these dynamics are especially pronounced for a halfie anthropologist, a positionality where "the Other is in certain ways the self" (AbuLughod 1991: 141). This implicates the anthropologist in particular ways with the world of her interlocutors, where she speaks not only as an 'outsider' but also as an 'insider' (Narayan 1993: 676). This, in turn, shapes the responsibilities, stakes, and risks she faces (Jones 1995: 61). My positionality of being both self and other to my research interlocutors in the Philippines varies from situation to situation (Castillo 2015a). There were moments when social, personal, and epistemic distance collapsed, for instance, when my interlocutors and I shared the stakes of certain critical events. There were also instances when this distance was heightened, such as when our differing social, class, and religious backgrounds became relevant in our interactions. With social media, these personal, political, and social entanglements, stakes, risks, and responsibilities are intensified, particularly in a context where social media is an important part of everyday life, sociality, and politics. Moreover, I contend that this positionality shapes researchers' social media practices.

\section{Evolving Facebook Use: Stakes and Insights}

I 'joined' FB in 2008 while still living in the Philippines, initially out of curiosity as many of my friends had shifted there from the social media platform Friendster. When I moved to Berlin in 2011 for my PhD studies, FB became my primary way of staying in touch with family and friends; for organizing academic, civic, and political events in Berlin that enable us to reach a wide audience in the diaspora and the Philippines; and for keeping up to date with news of the country, especially through posts from activists and civil society organizations. In fact, most of the news that I get on FB is not carried by mainstream media. This is particularly the case when it comes to news about the Bangsamoro region in Mindanao where, since 2011, I have been conducting 
long-term ethnographic research among adherents of the Moro Islamic Liberation Front (MILF) on violence and peacemaking.

Certain research processes became easier too as I eventually connected with some of my interlocutors on FB. These include organizing fieldwork logistics, getting feedback and consent on what I had written, asking for clarifications on data gaps, and exchanging opinions on current events. Additionally, I use FB to discuss possible collaborations and connect with a much broader network of NGOs, scholars, artists, and activists working on the Philippines. Utilizing FB for these matters has become commonplace in the country where this platform is a main mode of communication for personal and professional matters. But aside from work-related communication, keeping in touch via FB with research interlocutors-about our personal lives, seeking assistance from each other, and expressing care and solidarity, especially during difficult political situations and natural calamities-strengthened our bonds beyond the interview setting. As such, these social media-mediated interactions helped me maintain co-presence with my interlocutors despite my prolonged absence from my field sites.

Yet the increasing use of FB by my interlocutors and myself through the years compounded the security risks and ethical dilemmas of my research among adherents of the MILF, which, at that time, was engaged in a protracted war and peace negotiations for the Bangsamoro's right to self-determination. Being publicly linked to research interlocutors through FB, for instance, might endanger their anonymity in relation to my research. To mitigate this risk, I did not add as FB 'friends' interlocutors from one of my field sites where MILF adherents resided. I opted to do this even though adding acquaintances on FB has become a common part of Filipino sociality and would have helped me get in touch with them whenever I am in Berlin.

I became even more wary of how I use FB after it was revealed that third parties, including government agencies, can access users' private data without the users' consent or knowledge, as seen in the Cambridge Analytica exposés (Occeñola 2019). This makes much of the risks involved in FB use invisible. Given this, I adjusted my FB security settings and started to assume that whatever I say on FB Messenger might be accessible to third parties. This made me mindful of what I discuss on this chat platform. At the same time, I was constantly sensitive to how FB might endanger my security. Particularly from 2011 to 2014, I kept a low profile about my research due to the security risks involved, not only for my interlocutors but also for myself, which included the possibility of being kidnapped or being accused by authorities as a terrorist. I thus carefully scrutinized who I added on FB and was cautious about what I revealed on the platform about myself, my research, and my whereabouts when I was in the Philippines. However, this low profile changed in January 2015. 


\section{Becoming Visible: From Social Media to 'the Field'}

On the morning of 25 January 2015, as I started my day in Berlin, I opened FB to check on news back home. Scrolling through my News Feed, I became increasingly alarmed at the proliferation of posts about policemen who had entered areas that were government-recognized MILF camps, purportedly hunting for a "terrorist" wanted by the United States. The resultant clash between the police and various armed men led to the death of 44 policemen, 18 MILF fighters, and at least 7 Muslim civilians. I immediately contacted my research interlocutors on FB, anxious for their safety. We also discussed what was happening via e-mail, facilitated by our social media connectivity, as the events unfolded in the following days and weeks. In this way, I could somehow be 'in the moment' despite not being 'there' in Mindanao.

My interlocutors' nuanced views on the clash were in contrast to the antiMuslim rhetoric and calls for war against the MILF and Muslims from a broad swath of Philippine society, including politicians, scholars, and journalists (Castillo 2018). Absent in the latter's condemnation was any mention of the Muslim lives lost during the clash. It was distressing to see such violent and discriminatory rhetoric and sentiments against Muslims in my News Feed. It made me worry about research interlocutors whom I could not contact. I found it difficult to sleep, and had nightmares when I did. I finally decided to intervene in the caustic debate after a journalist's misinformed and inflammatory post.

I wrote in my FB post that I had been conducting fieldwork among MILF supporters in Mindanao and thus have a certain understanding of the complexities of the conflict. I enjoined fellow Filipinos to value Muslim lives as well and that in demanding accountability for the deaths of the policemen, people should also demand accountability for the human rights violations that government forces committed against Muslims. I asked, who do we condemn, and whose lives matter? To my surprise, my post was shared over a thousand times on FB. And upon the urging of several Filipino scholars, I published it as an opinion editorial in Rappler, one of the country's leading online news sites (Castillo 2015b).

The response to my post was overwhelmingly positive. Aside from those who commented on it and shared it, I also received messages on FB from research interlocutors and strangers, Muslim and non-Muslim Filipinos alike. One Muslim woman wrote to me saying, "Often, expressing similar thoughts to which you posted, which I couldn't possibly express any better, would usually be construed negatively given my religious beliefs and being one of the 'other'. So it's heartening to know there are those who understand where the 'other' are coming from." Among non-Muslims who sent me messages, the common theme was that my post helped them comprehend what was happening. A few did not like what I wrote, with some accusing me of being biased, while at the 
same time insisting that Moros or Muslims are violent and cannot be trusted. In a matter of days, my FB network of ordinary citizens, civil society workers, scholars, and activists increased. And so did my visibility as a scholar, which opened doors for collaborations. Moreover, the solidarity and activism I demonstrated further strengthened the bonds between me and my interlocutors with whom I talk on social media.

Yet I knew that in publishing my post, keeping my low profile for security reasons was no longer possible. I thus had to take extra security measures, such as in organizing my transportation in Mindanao a few months after the clash. A civil society worker and research interlocutor who helped me with this told me that my post and opinion editorial were widely shared among their networks, including within the MILF, and that many of them felt that it shifted the tone of the anti-Muslim and pro-war discourse. I realized then that despite the potential security risk of my social media visibility and intervention, it also created new ties that could protect me during fieldwork.

To be made to realize the power of an anthropological account "where it matters, when it matters," as one Filipina anthropologist told me in reaction to my FB post, is not a hubris of the discipline. Rather, it highlights our responsibilities as scholars. Correspondingly, it demonstrates how much care we have to put into our production of knowledge, and how difficult it is to always be up to that task, especially when our social media interventions can circulate so quickly and widely and garner immediate and direct reactions. As a halfie anthropologist, I cannot shirk these responsibilities despite the potential risks I outlined above. Nor can I easily escape the social media web in which I am entangled with my research interlocutors and my country's politics.

\section{Concluding Remarks}

I set out to discuss how my positionality as a halfie anthropologist and the centrality of Facebook in Filipinos' lives have shaped my engagement with FB and its implications for my personal life, my research, my interlocutors, activism, and Philippine politics more generally. The ubiquity and banality (Hine 2015: 8) of the Internet and social media in everyday life in many parts of the world render it an important dimension of our interaction with our interlocutors. This complicates the temporal, spatial, affective, and mental boundaries between 'home' and 'field' and personal and professional lives, how we negotiate these boundaries, and how we manage the seepage of the online into our offline lives. At the same time, social media connectivity and visibility create ethical issues, many of which are not easily detectable and which necessitate social media-specific ethical considerations. Nonetheless, social media connectivity presents advantages for research, networking, activism, and solidarity 
building. Equally significant, it can help democratize knowledge production and unsettle power hierarchies between researcher and researched.

One's engagement with social media is not static or uniform. It unfolds and evolves according to one's life trajectory and shifting personal, political, and academic needs and persuasions. Social media engagement is also shaped by access to technology, revelations on the security of social media platforms, digital and technological developments, and changing political contexts, among others. For instance, as social media continues to gain political importance in various parts of the world, so do efforts to utilize it toward undemocratic ends. In the Philippines, Facebook has been used to harass critics of President Rodrigo Duterte and to spread disinformation, which intensified starting in 2016 (Ong and Cabañes 2018; Ressa 2019). With the 2020 passage of the Anti-Terrorism Law, critics fear an increase in persecution over social media posts that are critical of the government. This signals another shift in the role of FB in Philippine society and politics that Filipino users must be cognizant of.

Given these risks, it seems wise to disengage from FB. But for me and perhaps for other similarly positioned scholars, doing so would mean not being able to keep in touch with family, friends, and interlocutors, which is important for me as a Filipina living abroad. It would also limit the reach of my research, networks, and activism. Thus, being personally, academically, and politically entangled in social media with research interlocutors, research sites, and colleagues necessitates knowing how to use it wisely. This includes understanding and mitigating its ethical and security issues, and carefully monitoring and thinking through its unfolding and multi-pronged advantages and challenges.

\section{Acknowledgments}

I would like to thank Anna-Maria Walter, Geoffrey Hughes, Eva Theunissen, and Fatima Alvarez-Castillo for their feedback.

Rosa Cordillera A. Castillo, PhD, is an anthropologist and engaged scholar based at the Institute for Asian and African Studies, Humboldt University Berlin. She works on peace and conflict studies, with a particular interest in violence and subjectivity, moral and ethical self-formation, affect and emotions, and resistance and solidarity. She is also interested in and has written on the anthropology of Islam, decoloniality, research ethics, and engaged scholarship. E-mail: rosa.castillo@hu-berlin.de 


\section{References}

Abu-Lughod, Lila. 1991. “Writing Against Culture.” In Recapturing Anthropology: Working in the Present, ed. Richard G. Fox, 137-162. Santa Fe, NM: School of American Research Press.

Beaulieu, Anne. 2010. "Research Note: From Co-location to Co-presence: Shifts in the Use of Ethnography for the Study of Knowledge." Social Studies of Science 40 (3): 453-470.

Castillo, Rosa Cordillera. 2015a. "The Emotional, Political, and Analytical Labor of Engaged Anthropology amidst Violent Political Conflict.” Medical Anthropology: Cross-Cultural Studies in Health and Illness 34 (1): 70-83.

Castillo, Rosa Cordillera. 2015b. "Mamasapano: Who Do We Condemn? Whose Lives Matter?” Rappler, 14 February. http://www.rappler.com/views/ imho/83885-mamasapano-lives-matter.

Castillo, Rosa Cordillera. 2018. "The Mamasapano Clash, Memories of Violence, and the Politics of Muslim Belonging in the Philippines.” New Mandala, 14 August. http://www.newmandala.org/ mamasapano-memories-muslim-belonging-philippines/.

Gupta, Akhil, and James Ferguson. 1997. "Discipline and Practice: 'The Field' as Site, Method, and Location in Anthropology." In Anthropological Locations: Boundaries and Grounds of a Field Science, ed. Akhil Gupta and James Ferguson, 1-46. Berkeley: University of California Press.

Hine, Christine. 2015. Ethnography for the Internet: Embedded, Embodied and Everyday. London: Bloomsbury Academic.

Jones, Delmos J. 1995. "Anthropology and the Oppressed: A Reflection on 'Native' Anthropology.” NAPA Bulletin 16 (1): 58-70. Special issue titled "Insider Anthropology," ed. E. L. Cerroni-Long.

Kemp, Simon. 2019. “Digital 2019: The Philippines.” DataReportal, 31 January. https://datareportal.com/reports/digital-2019-philippines.

Narayan, Kirin. 1993. "How Native Is a 'Native' Anthropologist?” American Anthropologist (n.s.) 95 (3): 671-686.

Occeñola, Paige. 2019. "Exclusive: PH Was Cambridge Analytica's 'Petri Dish' - Whistle-Blower Christian Wylie.” Rappler, 10 September. https://rappler.com/technology/social-media/ cambridge-analytica-philippines-online-propaganda-christopher-wylie.

Ong, Jonathan Corpus, and Jason Vincent A. Cabañes. 2018. "Architects of Networked Disinformation: Behind the Scenes of Troll Accounts and Fake News Production in the Philippines.” Scholarworks@UMassAmherst. https://doi. org/10.7275/2cq4-5396.

Ressa, Maria. 2019. “Facebook Let My Government Target Me: Here’s Why I Still Work with Them.” Time, 17 January. https://time.com/5505458/ facebook-maria-ressa-philippines/.

Spencer, Dimitrina. 2011. "Emotions and the Transformative Potential of Fieldwork: Some Implications for Teaching and Learning Anthropology.” Teaching Anthropology 1 (2): 68-97. 